\title{
Phytochemical Analysis, in vitro Antioxidant Activity and Inhibition of Key Diabetic Enzymes by Selected Nigerian Medicinal Plants with Antidiabetic Potential
}

\author{
Taofik Olatunde Sunmonu, Francis Bayo Lewu*
}

Department of Agriculture, Faculty of Applied Sciences, Cape Peninsula University of Technology, Wellington Campus, Wellington 7655, Western Cape, SOUTH AFRICA.

\begin{abstract}
Background: Diabetes is one of the most common metabolic disorders worldwide and the disease is generally believed to be incurable. However, the historical success of natural products as therapeutic agents has led to the search for more herbs with antidiabetic potential. Aim: To investigate the antioxidative and antidiabetic activities of some common medicinal plants traditionally used to treat diabetes in Nigeria. Materials and Methods: Twenty one plant samples comprising leaves, seeds and stem bark were separately extracted using three solvents of increasing polarity namely ethanol, methanol and distilled water. The extracts were subsequently screened for their phenolic profile, ferric reducing power as well as inhibition of $\alpha$-amylase and haemoglobin glycosylation activities as markers of in vitro antidiabetic activity. Results: Solvents extracts of 7 out of the 21 plants examined namely Anacardium occidentale (leaf), Carica papaya (leaf), Ficus asperifolia (leaf), Hibiscus sabdariffa (stem bark), Khaya senegalensis (stem bark), Ocimum gratissimum (leaf) and Parkia biglobosa (stem bark) had significant concentrations of total polyphenol and flavonoid compared to the other plants. Similarly, for all the in vitro models used in this study, the same set of plants demonstrated significantly $(p<0.05)$ higher effects which were comparable to ascorbic acid, acarbose and gallic acid. Conclusion: Findings from this study indicate strong correlation between polyphenolic concentration and antidiabetic activity. The study also confirmed the potential of some Nigerian herbs in antidiabetic drug discovery; and identified a number of promising plants for further in vivo investigation as plant-based antidiabetic agents.
\end{abstract}

Key words: Diabetes, Antioxidant, $\alpha$-amylase, Haemoglobin glycosylation, Natural products.

\section{INTRODUCTION}

Diabetes mellitus is a metabolic disease characterized by high blood glucose level resulting from defects in insulin secretion, insulin action or both. ${ }^{1}$ It is a common and prevalent disease affecting people in both developed and developing countries. Worldwide, the prevalence of diabetes mellitus is on the rise with a projected $5.4 \%$ increase by 2025. ${ }^{2}$ According to International Diabetes Federation, there are about 387 million people afflicted with diabetes worldwide, with 22 million residing in sub-Saharan Africa. Nigeria is the most populated country in Africa and is home to 4 million people with diabetes, representing a fifth of all diabetes cases in sub-Saharan Africa. More worrisome is the fact that about $70 \%-80 \%$ of the diabetes cases in Nigeria remain undiagnosed or untreated. ${ }^{3}$ According to the most recent information on the prevalence of diabetes in South Africa, ${ }^{4}$ about $6 \%$ of the population have confirmed and latent cases of diabetes with a possible sharp rise in this number in the nearest future. Despite these alarming statistics, diabetes still remain one of the age long chronic diseases of human race and its frontiers are expanding by the day.
Submission Date: 09-07-2018; Revision Date: 31-10-2018; Accepted Date: 29-12-2018

DOI: 10.5530/ijper.53.2.33 Correspondence:

Prof. Francis Bayo Lewu, Department of Agriculture, Faculty of Applied Sciences, Cape Peninsula University of Technology, Wellington Campus, Wellington 7655, Western Cape, SOUTH AFRICA.

Phone: +27 218645213

E-mail: LewuF@cput.ac.za

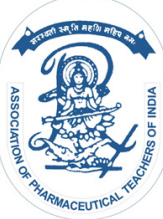

www.ijper.org 
On the basis of aetiology and clinical presentation, diabetes mellitus is classified into two namely type 1 and type 2 diabetes. Type 1, known as insulin-dependent diabetes mellitus (IDDM) is caused by immunological destruction of pancreatic $\beta$ cells resulting in insulin deficiency. ${ }^{5}$ It is mainly triggered by environmental factors that may activate autoimmune mechanisms in genetically susceptible individuals, leading to progressive loss of pancreatic islet $\beta$ cells. ${ }^{6}$ Type 2 diabetes, also known as non-insulin-dependent diabetes mellitus (NIDDM), is characterized by both impaired insulin secretion and insulin resistance; and it is often associated with sedentary lifestyle, obesity and hereditary disposition. ${ }^{7}$

Recently, free radical generation has been suggested to play an important role in the cause and complications of diabetes. ${ }^{8}$ These radicals are continually produced in the body as a result of normal metabolic processes and interaction with environmental stimuli. In healthy individuals, generation of free radical appears to be approximately in balance with the antioxidant defense system comprising both enzymatic and non-enzymatic antioxidants. In diabetic state however, there are alterations in the endogenous free radical scavenging mechanisms which may lead to the production of reactive oxygen species, resulting in oxidative damage and tissue injury. ${ }^{9}$ The implication of oxidative stress in the pathogenesis of diabetes is suggested not only by oxygen-free radicals but also due to non-enzymatic protein glycosylation and auto-oxidation of glucose, ${ }^{10}$ alterations in antioxidant enzymes $^{11}$ as well as formation of lipid peroxides. ${ }^{12}$ Enhanced oxidative stress and changes in antioxidant capacity, observed in both clinical and experimental diabetes, are thought to be the etiology of diabetic complications. ${ }^{12}$

The management of diabetes is considered a global problem and the search for a definite therapy is still ongoing. A few chemotherapeutic drugs have been used to manage the disease; however the application of these drugs is limited due to their high cost and associated side effects. In the last few years, attention is being focused on the identification of natural products from plants to replace the synthetic drugs. Consequently, there has been an exponential growth in the use of herbal medicine because of its natural origin and less side effects. ${ }^{13}$ This approach continues to play an important role in diabetic therapy, particularly in developing countries where many people have limited resources and do not have access to modern treatment. ${ }^{14}$

In Nigeria, the list of plant species identified for the treatment of diabetes based on traditional folklore medicine is endless; particularly in the Central, Eastern and Western regions which are recognized as the richest flora communities in Nigeria. Unfortunately, there is no scientific basis for the use of many of such plants as antidiabetic agents. Therefore, the present study was designed to investigate the in vitro antidiabetic activity of different parts of 21 commonly used medicinal plants in Nigeria extracted using three solvents namely ethanol, methanol and distilled water. This is of great importance in order to lend scientific credence to the use of the herbs for the treatment of diabetes by traditional healers.

\section{MATERIALS AND METHODS \\ Chemicals and reagents}

Folin-Ciocalteau reagent, hexane, methanol and ethanol were products of Merck Chemical Company (Darmstadt, Germany). Ascorbic acid, tannic acid, quercetin, hemoglobin, gallic acid, aluminum chloride, $\alpha$-amylase and ferric chloride were purchased from Sigma Chemical Co. (St. Louis, MO, USA). Gentamycin was purchased from EMD-Chemicals, San Diego, CA, USA. All other chemicals and reagents were of analytical grade.

\section{Plant materials}

Twenty one medicinal plants comprising leaves, seeds and stem bark were freshly collected in November, 2016 from local villages across Kwara, Kogi and Ekiti States in Nigeria, West Africa. The plants and parts are Alchornea cordifolea (leaf), Anacardium occidentale (leaf), Anthocleista djalonensis (leaf), Bridelia ferruginea (leaf, seed and stem bark), Carica papaya (leaf), Ceiba pentandra (stem bark), Citrus paradisi (leaf), Cnestis ferruginea (leaf), Ficus asperifolia (leaf), Ficus exasperata (leaf), Gongronema latifolium (leaf), Hibiscus sabdariffa (stem bark), Hunteria umbellata (seed), Indigofera pulchra (leaf), Khaya senegalensis (leaf and stem bark), Mangifera indica (leaf and stem bark), Morinda lucida (leaf), Nauclea latifolia (leaf), Ocimum gratissimum (leaf), Parkia biglobosa (stem bark) and Viscum album (leaf and seed). The plants were identified and authenticated at the Herbarium Unit of the Department of Plant Biology, University of Ilorin, Nigeria by Mr. Bolu Ajayi and tagged with appropriate voucher numbers (Table 1). Specimen samples were thereafter prepared and deposited accordingly at the Herbarium of the University.

\section{Preparation of plant samples}

The plant samples were treated as previously described. ${ }^{15}$ Briefly, the samples were thoroughly rinsed under running tap water followed by distilled water to cleanse them of dirt, dust and debris. They were thereafter shade-dried for two weeks to constant weights. The 


\begin{tabular}{|c|c|}
\hline Plants & Voucher Number \\
\hline Alchornea cordifolea & UILH/002/666 \\
\hline Anacardium occidentale & UILH/003/612 \\
\hline Anthocleista djalonensis & UILH/001/1248 \\
\hline Bridelia ferruginea & UILH/002/988 \\
\hline Carica papaya & UILH/003/945 \\
\hline Ceiba pentandra & UILH/001/957 \\
\hline Citrus paradisi & UILH/001/995 \\
\hline Cnestis ferruginea & UILH/001/1034 \\
\hline Ficus asperifolia & UILH/001/1210 \\
\hline Ficus exasperata & U1LH/001/883 \\
\hline Gongronema latifolium & UILH/002/1196 \\
\hline Hibiscus sabdariffa & UILH/003/646 \\
\hline Hunteria umbellata & UILH/001/1151 \\
\hline Indigofera pulchra & ULLH/002/421 \\
\hline Khaya senegalensis & UILH/001/852 \\
\hline Mangifera indica & UILH/003/490 \\
\hline Morinda lucida & UILH/002/1103 \\
\hline Nauclea latifolia & UILH/002/806 \\
\hline Ocimum gratissimum & UILH/003/984 \\
\hline Parkia biglobosa & UILH/003/313 \\
\hline Viscum album & UILH/001/1210 \\
\hline
\end{tabular}

dried samples were milled to a fine powder and then stored separately in airtight containers for transport to Cape Peninsula University of Technology, Wellington Campus, South Africa for further analyses.

\section{Preparation of plant extracts}

Using $200 \mathrm{~mL}$ of hexane, $30 \mathrm{~g}$ each of the powdered samples were defatted before they were separately extracted with $200 \mathrm{~mL}$ of ethanol, methanol and distilled water by soaking for $48 \mathrm{~h}$. This was followed by $2 \mathrm{~h}$ orbital shaking at $200 \mathrm{rpm}$ to allow for maximum extraction before filtration using Whatman No. 1 filter paper. The ethanol and methanol extracts were evaporated at $40^{\circ} \mathrm{C}$ under reduced pressure using a rotary evaporator while the distilled water extract was dried on a water bath at $45^{\circ} \mathrm{C}$. The resulting extract in each case was then weighed and transferred into sample bottles for storage in a refrigerator at $4^{\circ} \mathrm{C}$ until required for further analyses.

\section{Estimation of total polyphenol content}

The total polyphenol content of each extract was determined according to the method described by Wolfe et al. ${ }^{16}$ with slight modifications. Briefly, $200 \mu \mathrm{L}$ of each solvent extract $(240 \mu \mathrm{g} / \mathrm{mL})$ was incubated with $1 \mathrm{~mL}$ of Folin Ciocalteau reagent (previously diluted with water $1: 10 \mathrm{v} / \mathrm{v}$ ) and $800 \mu \mathrm{L}$ of $0.7 \mathrm{M}$ sodium carbonate for $30 \mathrm{~min}$ at room temperature for colour development. The absorbance of the reaction mixture was then measured at $765 \mathrm{~nm}$ using Advance UV/VIS Model SE 807 Spectrophotometer (India) and all measurements were taken in triplicate.

\section{Determination of total flavonoid content}

The total flavonoid content of the plant extracts was determined using the method described by Ordon Ez et al. ${ }^{17}$ A volume of $500 \mu \mathrm{L}(240 \mu \mathrm{g} / \mathrm{mL})$ of each sample was mixed with $500 \mu \mathrm{L}$ of methanol, $50 \mu \mathrm{L}$ of $10 \%$ aluminum chloride, $50 \mu \mathrm{L}$ of $1 \mathrm{~mol} / \mathrm{L}$ potassium acetate and $1.4 \mathrm{~mL}$ distilled water. After one hour at room temperature, the absorbance of the reaction mixture was measured in triplicate at $420 \mathrm{~nm}$ using Advance UV/VIS Model SE 807 Spectrophotometer (India).

\section{Assay of ferric reducing antioxidant power}

The ferric reducing potential of the extracts was assayed as described by Oyaizu ${ }^{18}$ with slight modifications. Volume of $1 \mathrm{~mL}$ of each extracts at different concentrations $(30,60,120$ and $240 \mu \mathrm{g} / \mathrm{mL})$ were incubated with $1 \mathrm{~mL}$ each of $0.2 \mathrm{M}$ sodium phosphate buffer at $\mathrm{pH} 6.6$ and $1 \%$ potassium ferricyanide. After $30 \mathrm{~min}$ of incubation at $50^{\circ} \mathrm{C}$, the reaction mixture was acidified with $1 \mathrm{~mL}$ of $10 \%$ trichloroacetic acid after which $1 \mathrm{~mL}$ of the acidified sample was mixed with $1 \mathrm{~mL}$ distilled water and $200 \mu \mathrm{L}$ of $0.1 \% \mathrm{FeCl}_{3}$. The absorbance was measured at $700 \mathrm{~nm}$ using Advance UV/VIS Model SE 807 Spectrophotometer (India). The reducing power of the extracts was compared with ascorbic acid.

\section{Assay of $\alpha$-amylase inhibitory effect}

The inhibition of $\alpha$-amylase can be measured in vitro by hydrolysis of starch in the presence of $\alpha$-amylase enzyme. The $\alpha$-amylase inhibitory effect of the plant extracts was carried out according to the modified method of McCue and Shetty. ${ }^{19}$ Briefly, $250 \mu \mathrm{L}$ of each extract at different concentrations $(30,60,120$ and $240 \mu \mathrm{g} / \mathrm{mL}$ ) were measured followed by addition of $250 \mu \mathrm{L}$ of $0.02 \mathrm{M}$ sodium phosphate buffer ( $\mathrm{pH}$ 6.9) containing $\alpha$-amylase solution. The solution was pre- incubated at $25^{\circ} \mathrm{C}$ for $10 \mathrm{~min}$ followed by addition of $250 \mu \mathrm{L}$ of $1 \%$ starch solution in $0.02 \mathrm{M}$ sodium phosphate buffer ( $\mathrm{pH}$ 6.9) at time intervals of $10 \mathrm{sec}$. The resulting solution was further incubated at $25^{\circ} \mathrm{C}$ for $10 \mathrm{~min}$ and the reaction was terminated by adding $1 \mathrm{~mL}$ of dinitrosalicyclic acid (DNS) reagent. The reaction mixture was then boiled for $10 \mathrm{~min}$, cooled at room temperature and diluted with $5 \mathrm{~mL}$ of distilled water before taking absorbance at $540 \mathrm{~nm}$ using Advance UV/VIS Model SE 807 Spectrophotometer (India). Control and standard 
were prepared alongside using the same procedure but replacing the extract with distilled water and acarbose respectively. The percentage inhibition was calculated as follows:

$[$ Absorbance of control -
Percentage inhibition $=\frac{\text { Absorbance of Extract }]}{[\text { Absorbance of Control }} \times 100$

\section{Assay of inhibition of hemoglobin glycosylation}

The inhibition of non-enzymatic glycosylation of haemoglobin by different extracts was assayed following the method described by Pal and Dutta. ${ }^{20}$ Briefly, $1 \mathrm{~mL}$ each of glucose $(2 \%)$, hemoglobin $(0.06 \%)$ and gentamycin $(0.02 \%)$ prepared in $0.01 \mathrm{M}$ phosphate buffer at $\mathrm{pH} 7.4$ were mixed with $1 \mathrm{~mL}$ of each extract at different concentrations $(30,60,120$ and $240 \mu \mathrm{g} / \mathrm{mL})$ which were dissolved in dimethyl sulfoxide (DMSO). The mixture was incubated in the dark at room temperature for $72 \mathrm{~h}$ after which absorbance was measured at $520 \mathrm{~nm}$ using Advance UV/VIS Model SE 807 Spectrophotometer (India) with gallic acid as the standard. The percentage inhibition was calculated according to the following formula:

[Absorbance of Control -

Percentage inhibition $=\frac{\text { Absorbance of Extract }]}{[\text { Absorbance of Control }} \times 100$

\section{Statistical analysis}

Data were analyzed using SPSS/10 with the results expressed as mean \pm Standard deviation (SD) for five determinations. Statistical evaluations were assayed using one-way analysis of variance (ANOVA) followed by Tukey's post hoc test for multiple comparison. Differences between means were considered statistically significant at $p<0.05$.

\section{RESULTS}

The yields recovered from ethanol, methanol and distilled water extraction of different plant parts are presented in Table 2. The distilled water extract of $C$. paradisi leaf gave the highest yield of $13.80 \mathrm{~g}$ followed by distilled water and ethanol extracts of C. papaya leaf with $11.65 \mathrm{~g}$ and $9.33 \mathrm{~g}$ respectively. The lowest recovery of $0.04 \mathrm{~g}$ was obtained from methanol extract of $M$. indica stem bark. Generally, methanol extracts gave lower yields while distilled water extraction produced higher recovery when compared with ethanol and methanol.

The concentrations of polyphenol and flavonoid in the solvent extracts of different plant parts are presented in Tables 3 and 4. A. occidentale leaf stood out as all

\begin{tabular}{|c|c|c|c|}
\hline \multicolumn{4}{|c|}{ Extract/Yield (\%) } \\
\hline Plant/Part & Ethanol & Methanol & $\begin{array}{l}\text { Distilled } \\
\text { Water }\end{array}$ \\
\hline A. cordifolea Leaf & 1.93 & 8.60 & 7.17 \\
\hline A. occidentale Leaf & 8.45 & 1.10 & 3.23 \\
\hline A. djalonensis Leaf & 0.93 & 0.50 & 5.48 \\
\hline B. ferruginea Leaf & 2.90 & 5.97 & 7.20 \\
\hline B. ferruginea Seed & 2.21 & 1.50 & 3.30 \\
\hline B. ferruginea Stem Bark & 3.20 & 3.33 & 3.80 \\
\hline C. papaya Leaf & 9.33 & 5.25 & 11.65 \\
\hline C. pentandra Stem Bark & 1.40 & 3.33 & 2.53 \\
\hline C. paradisi Leaf & 2.45 & 1.05 & 13.80 \\
\hline C. ferruginea Leaf & 2.25 & 1.80 & 5.43 \\
\hline F. asperifolia Leaf & 2.50 & 0.90 & 3.78 \\
\hline F. exasperata Leaf & 0.63 & 0.70 & 3.38 \\
\hline G. Iatifolium Leaf & 3.50 & 4.10 & 7.76 \\
\hline H. sabdariffa Stem Bark & 2.93 & 1.08 & 8.60 \\
\hline H. umbellata Seed & 2.53 & 3.10 & 5.70 \\
\hline I. pulchra Leaf & 1.53 & 0.60 & 6.20 \\
\hline K. senegalensis Leaf & 4.03 & 3.63 & 7.40 \\
\hline K. senegalensis Stem Bark & 6.78 & 1.18 & 6.48 \\
\hline M. indica Leaf & 4.03 & 5.23 & 5.90 \\
\hline M. indica Stem Bark & 7.05 & 0.40 & 1.53 \\
\hline M. Lucida Leaf & 0.60 & 0.63 & 8.10 \\
\hline N. latifolia Leaf & 1.85 & 2.55 & 1.13 \\
\hline O. gratissimum Leaf & 4.18 & 2.08 & 6.40 \\
\hline P. biglobosa Stem Bark & 4.60 & 0.80 & 2.56 \\
\hline V. album Leaf & 1.50 & 2.10 & 5.48 \\
\hline V. album Seed & 3.13 & 4.50 & 5.36 \\
\hline
\end{tabular}

the three extracts (ethanol, methanol and distilled water) were characterized by the presence of significant $(p<0.05)$ high concentrations of total polyphenol and flavonoid compared to other solvent extracts of the same or different plant parts. Other plants with significant concentration of polyphenol include C. papaya leaf, $F$. asperifolia leaf, $H$. sabdariffa stem bark, $K$. senegalensis stem bark, O. gratissimum leaf and P. biglobosa stem bark (Table 3). For flavonoid content, we observed that the same set of plants showed significant higher concentration with slight difference in the solvent (Table 4). The data obtained in respect of ferric reducing antioxidant power indicated that the reductive capability of the extracts was concentration dependent with $240 \mu \mathrm{g} / \mathrm{mL}$ giving the best result. This concentration was therefore chosen to assess the antioxidant potential of the plants studied (Table 5). The results showed that solvent 


\begin{tabular}{|c|c|c|c|}
\hline \multicolumn{4}{|c|}{ Extracts } \\
\hline Plant/Part & Ethanol & Methanol & Distilled Water \\
\hline A. cordifolea Leaf & $6.42 \pm 0.46^{a}$ & $6.10 \pm 0.43^{a}$ & $5.51 \pm 0.54^{a}$ \\
\hline A. occidentale Leaf & $53.95 \pm 5.12^{\mathrm{a}^{* *}}$ & $48.07 \pm 4.07^{b^{* *}}$ & $40.67 \pm 3.96^{\mathrm{c}^{* *}}$ \\
\hline A. djalonensis Leaf & $1.61 \pm 0.14^{a}$ & $1.53 \pm 0.16^{a}$ & $2.31 \pm 0.14^{b}$ \\
\hline B. ferruginea Leaf & $4.43 \pm 0.08^{a}$ & $3.83 \pm 0.04^{\mathrm{a}}$ & $5.30 \pm 0.08^{b}$ \\
\hline B. ferruginea Seed & $0.46 \pm 0.08^{a}$ & $0.86 \pm 0.05^{\mathrm{a}}$ & $1.53 \pm 0.05^{b}$ \\
\hline B. ferruginea Stem Bark & $1.88 \pm 0.60^{\mathrm{a}}$ & $1.72 \pm 0.09^{a}$ & $5.03 \pm 0.05^{b}$ \\
\hline C. papaya Leaf & $33.52 \pm 1.77^{a}$ & $20.60 \pm 2.87^{a}$ & $47.63 \pm 3.40^{\mathrm{b}^{* *}}$ \\
\hline C. pentandra Stem Bark & $6.06 \pm 0.05^{a}$ & $10.90 \pm 0.09^{b}$ & $3.83 \pm 0.08^{c}$ \\
\hline C. paradisi Leaf & $2.15 \pm 0.06^{\mathrm{a}}$ & $1.71 \pm 0.03^{b}$ & $2.03 \pm 0.05^{\mathrm{a}}$ \\
\hline C. ferruginea Leaf & $1.47 \pm 0.04^{a}$ & $1.30 \pm 0.06^{a}$ & $1.87 \pm 0.03^{b}$ \\
\hline F. asperifolia Leaf & $16.61 \pm 0.89^{a}$ & $27.82 \pm 1.00^{b}$ & $44.58 \pm 4.27^{\mathrm{c}^{* *}}$ \\
\hline F. exasperata Leaf & $1.23 \pm 0.04^{\mathrm{a}}$ & $1.24 \pm 0.01^{\mathrm{a}}$ & $1.22 \pm 0.01^{\mathrm{a}}$ \\
\hline G. latifolium Leaf & $1.38 \pm 0.02^{\mathrm{a}}$ & $1.06 \pm 0.02^{b}$ & $1.09 \pm 0.04^{b}$ \\
\hline H. sabdariffa Stem Bark & $24.19 \pm 1.22^{\mathrm{a}}$ & $12.25 \pm 0.76^{b}$ & $40.39 \pm 4.20^{\mathrm{c}^{* *}}$ \\
\hline H. umbellata Seed & $0.34 \pm 0.02^{\mathrm{a}}$ & $0.45 \pm 0.03^{b}$ & $0.31 \pm 0.02^{\mathrm{a}}$ \\
\hline I. pulchra Leaf & $1.77 \pm 0.02^{a}$ & $2.24 \pm 0.04^{b}$ & $1.94 \pm 0.05^{a}$ \\
\hline K. senegalensis Leaf & $4.80 \pm 0.17^{a}$ & $4.38 \pm 0.30^{\mathrm{a}}$ & $3.18 \pm 0.09^{b}$ \\
\hline K. senegalensis Stem Bark & $16.56 \pm 1.91^{\mathrm{a}}$ & $11.20 \pm 0.57^{b}$ & $42.40 \pm 4.80^{\mathrm{c}^{* *}}$ \\
\hline M. indica Leaf & $3.92 \pm 0.17^{a}$ & $4.20 \pm 0.11^{a}$ & $3.74 \pm 0.15^{\mathrm{a}}$ \\
\hline M. indica Stem Bark & $14.36 \pm 0.16^{\mathrm{a}}$ & $4.74 \pm 0.04^{b}$ & $12.22 \pm 0.18^{c}$ \\
\hline M. Lucida Leaf & $0.64 \pm 0.06^{\mathrm{a}}$ & $0.88 \pm 0.06^{\mathrm{a}}$ & $0.54 \pm 0.05^{\mathrm{a}}$ \\
\hline N. latifolia Leaf & $1.88 \pm 0.06^{a}$ & $2.15 \pm 0.09^{a}$ & $5.37 \pm 0.05^{b}$ \\
\hline O. gratissimum Leaf & $39.30 \pm 5.43^{\mathrm{a}^{* *}}$ & $11.00 \pm 1.02^{b}$ & $42.60 \pm 4.06^{\mathrm{c}^{* *}}$ \\
\hline P. biglobosa Stem Bark & $42.84 \pm 3.64^{\mathrm{a}^{* *}}$ & $14.45 \pm 0.60^{\mathrm{b}}$ & $24.12 \pm 0.70^{c}$ \\
\hline V. album Leaf & $3.33 \pm 0.08^{a}$ & $3.11 \pm 0.02^{\mathrm{a}}$ & $1.72 \pm 0.05^{b}$ \\
\hline V. album Seed & $0.91 \pm 0.03^{a}$ & $0.74 \pm 0.01^{a}$ & $0.41 \pm 0.02^{b}$ \\
\hline
\end{tabular}

Data are presented as mean $\pm S D$ of three replicates at $240 \mu \mathrm{g} / \mathrm{ml}$. Values with different letters along the same row for each plant part are significantly different $(p<0.05)$, ** indicate highly significant $(p<0.05)$ difference.

extracts of $A$. occidentale leaves demonstrated significant $(p<0.05)$ higher ferric reducing activity when compared to other plants; with the ethanol and distilled water extracts of the plant showing better activity when compared with ascorbic acid. Interestingly, all the plants reported to have high concentrations of polyphenol and flavonoid in this study also exhibited strong ferric reducing power comparable to ascorbic acid (Table 5). Generally, plant parts extracted with distilled water showed better antioxidant activity compared to ethanol and methanol irrespective of the plant parts.

In this study, the inhibition of $\alpha$-amylase and haemoglobin glycosylation by plant extracts was also best at $240 \mu \mathrm{g} / \mathrm{mL}$; hence the choice of this concentration to assess these parameters (Tables 6 and 7). It was clearly observed that leaf extracts of $A$. occidentale, C. papaya, F. asperifolia, O. gratissimum as well as stem bark extracts of $H$. sabdariffa, $K$. senegalensis and P. biglobosa exhibited significant $(p<0.05)$ higher inhibitory effect which was comparable to acarbose and gallic acid (Tables 6 and 7).

\section{DISCUSSION}

The administration of herbal preparations with regards to diabetes treatment has raised concerns due to absence of adequate scientific basis for their efficacy and safety. However, the present study has clearly demonstrated the potential of some of the traditionally employed medicinal plants in Nigeria as antidiabetic agents.

Polyphenols and flavonoids are the major plant components with antioxidant activity and it is likely that the medicinal properties of plant extracts may be due to the redox properties of these compounds. Previous studies have implicated polyphenols and other related com- 


\section{Table 4: Total Flavonoid Content (mg/g QE) in Solvent Extracts of Different Plant Parts.}

\begin{tabular}{|c|c|c|c|}
\hline \multicolumn{4}{|c|}{ Extracts } \\
\hline Plant/Part & Ethanol & Methanol & Distilled Water \\
\hline A. cordifolea Leaf & $0.45 \pm 0.06^{a}$ & $0.48 \pm 0.04^{a}$ & $0.42 \pm 0.04^{a}$ \\
\hline A. occidentale Leaf & $38.58 \pm 4.63^{\mathrm{a}^{* *}}$ & $35.83 \pm 5.02^{b^{* *}}$ & $31.08 \pm 4.27^{\mathrm{c}^{* *}}$ \\
\hline A. djalonensis Leaf & $4.04 \pm 0.12^{\mathrm{a}}$ & $2.34 \pm 0.17^{b}$ & $6.01 \pm 0.14^{c}$ \\
\hline B. ferruginea Leaf & $4.45 \pm 0.10^{\mathrm{a}}$ & $3.15 \pm 0.11^{b}$ & $4.77 \pm 0.16^{a}$ \\
\hline B. ferruginea Seed & $0.14 \pm 0.01^{a}$ & $0.14 \pm 0.01^{a}$ & $0.30 \pm 0.01^{b}$ \\
\hline B. ferruginea Stem Bark & $3.95 \pm 0.15^{\mathrm{a}}$ & $3.50 \pm 0.11^{a}$ & $6.83 \pm 0.63^{b}$ \\
\hline C. papaya Leaf & $16.43 \pm 1.81^{a}$ & $10.00 \pm 0.49^{b}$ & $28.83 \pm 5.03^{\mathrm{c}^{* *}}$ \\
\hline C. pentandra Stem Bark & $4.00 \pm 0.12^{\mathrm{a}}$ & $8.08 \pm 0.34^{b}$ & $5.63 \pm 0.17^{c}$ \\
\hline C. paradisi Leaf & $4.13 \pm 0.07^{a}$ & $3.55 \pm 0.10^{b}$ & $4.01 \pm 0.13^{\mathrm{a}}$ \\
\hline C. ferruginea Leaf & $5.49 \pm 0.12^{\mathrm{a}}$ & $5.48 \pm 0.10^{\mathrm{a}}$ & $6.53 \pm 0.10^{b}$ \\
\hline F. asperifolia Leaf & $11.00 \pm 0.86^{a}$ & $22.50 \pm 1.59^{b}$ & $32.75 \pm 4.06^{\mathrm{c}^{* *}}$ \\
\hline F. exasperata Leaf & $0.85 \pm 0.02^{\mathrm{a}}$ & $0.88 \pm 0.06^{a}$ & $0.83 \pm 0.01^{a}$ \\
\hline G. Iatifolium Leaf & $0.88 \pm 0.02^{\mathrm{a}}$ & $0.76 \pm 0.01^{a}$ & $0.86 \pm 0.01^{a}$ \\
\hline H. sabdariffa Stem Bark & $12.83 \pm 0.76^{a}$ & $10.75 \pm 0.50^{a}$ & $26.36 \pm 3.91^{b^{* *}}$ \\
\hline H. umbellata Seed & $0.33 \pm 0.03^{a}$ & $0.41 \pm 0.02^{\mathrm{a}}$ & $0.26 \pm 0.04^{\mathrm{a}}$ \\
\hline I. pulchra Leaf & $0.45 \pm 0.01^{\mathrm{a}}$ & $0.85 \pm 0.03^{b}$ & $0.71 \pm 0.04^{b}$ \\
\hline K. senegalensis Leaf & $1.53 \pm 0.12^{\mathrm{a}}$ & $1.39 \pm 0.08^{a}$ & $1.30 \pm 0.14^{a}$ \\
\hline K. senegalensis Stem Bark & $27.80 \pm 4.08^{\mathrm{a}^{* *}}$ & $13.20 \pm 1.04^{b}$ & $31.80 \pm 4.04^{\mathrm{c}^{* *}}$ \\
\hline M. indica Leaf & $4.53 \pm 0.53^{\mathrm{a}}$ & $8.16 \pm 0.67^{b}$ & $4.12 \pm 0.39^{a}$ \\
\hline M. indica Stem Bark & $30.50 \pm 1.33^{a}$ & $12.50 \pm 0.58^{b}$ & $21.04 \pm 0.67^{c}$ \\
\hline M. Lucida Leaf & $0.19 \pm 0.02^{\mathrm{a}}$ & $0.49 \pm 0.04^{b}$ & $0.36 \pm 0.08^{c}$ \\
\hline N. latifolia Leaf & $2.07 \pm 0.04^{a}$ & $2.87 \pm 0.02^{b}$ & $3.84 \pm 0.08^{c}$ \\
\hline O. gratissimum Leaf & $29.69 \pm 4.18^{a^{* *}}$ & $4.48 \pm 0.56^{b}$ & $16.05 \pm 2.28^{c}$ \\
\hline P. biglobosa Stem Bark & $27.50 \pm 4.30^{\mathrm{a}^{* *}}$ & $10.15 \pm 0.47^{b}$ & $19.38 \pm 1.04^{c}$ \\
\hline V. album Leaf & $4.77 \pm 0.31^{a}$ & $3.98 \pm 0.43^{a}$ & $3.86 \pm 0.35^{\mathrm{a}}$ \\
\hline V. album Seed & $0.63 \pm 0.03^{a}$ & $0.62 \pm 0.02^{a}$ & $0.60 \pm 0.02^{a}$ \\
\hline
\end{tabular}

Data are presented as mean \pm SD of three replicates at $240 \mu \mathrm{g} / \mathrm{ml}$. Values with different letters along the same row for each plant part are significantly different $(p<0.05)$, ** indicate highly significant $(p<0.05)$ difference.

pounds in a number of therapeutic potentials including antioxidant, antidiabetic, anticancer and antimicrobial effects. ${ }^{21}$ In fact, most of the medicinal applications of plant-based formulations have been correlated to the polyphenols present in such plant species. ${ }^{22}$ In the current study, extracts of seven plants namely $A$. occidentale, C. papaya, F. asperifolia, H. sabdariffa, K. senegalensis, $O$. gratissimum and $P$. biglobosa comprising leaf and stem bark possessed considerable concentrations of polyphenol and flavonoid. Earlier reports have shown strong correlations between polyphenol content and antioxidant activity in many medicinal plants. ${ }^{23,24}$ Hodzic et $a .^{25}$ also reported that the concentration of polyphenols has a considerable impact on the antioxidant capacity of plant extracts. These compounds play an important role in adsorbing and neutralizing free radicals, quenching singlet and triplet oxygen or decomposing peroxides. ${ }^{26}$ The hydroxyl groups attached to the aromatic ring structure of flavonoid enable them to undergo redox reaction and consequently scavenge free radicals. ${ }^{27}$ This is an indication that extracts from the seven plants mentioned earlier possess considerable antioxidant properties. Consistent with this study, the antioxidant and antidiabetic activities of $A$. melegueta was attributed to rich content of flavonoids and other phenolics. ${ }^{22,28,29}$ Findings from the present study therefore indicate that polyphenols and flavonoids form major components of A. occidentale, C. papaya, F. asperifolia, H. sabdariffa, $K$. senegalensis, $O$. gratissimum and $P$. biglobosa; suggesting that their antioxidant and antidiabetic activities could be attributed to the presence of these valuable compounds.

The reducing power of a compound is related to its electron transfer ability and may serve as an indicator 


\section{Table 5: Percentage Ferric Reducing Antioxidant Power of Solvent Extracts of Different Plant Parts} Relative to Ascorbic Acid.

\begin{tabular}{|c|c|c|c|c|}
\hline \multicolumn{4}{|c|}{ Extracts } & \multirow[b]{2}{*}{ Ascorbic acid } \\
\hline Plant/Part & Ethanol & Methanol & Distilled Water & \\
\hline A. cordifolea Leaf & $23.73 \pm 1.28^{a}$ & $29.43 \pm 2.24^{b}$ & $10.35 \pm 0.60^{c}$ & $61.60 \pm 2.96^{d}$ \\
\hline A. occidentale Leaf & $74.53 \pm 3.32^{\mathrm{a}^{* *}}$ & $60.41 \pm 1.60^{b^{* *}}$ & $68.07 \pm 1.07^{\mathrm{a}^{* *}}$ & $61.60 \pm 2.96^{b}$ \\
\hline A. djalonensis Leaf & $12.48 \pm 0.78^{a}$ & $8.73 \pm 0.93^{b}$ & $13.80 \pm 0.66^{a}$ & $61.60 \pm 2.96^{c}$ \\
\hline B. ferruginea Leaf & $18.42 \pm 0.16^{a}$ & $16.98 \pm 0.80^{\mathrm{a}}$ & $26.82 \pm 1.03^{b}$ & $61.60 \pm 2.96^{c}$ \\
\hline B. ferruginea Seed & $11.42 \pm 0.90^{\mathrm{a}}$ & $14.23 \pm 0.37^{\mathrm{a}}$ & $20.37 \pm 2.06^{b}$ & $61.60 \pm 2.96^{c}$ \\
\hline B. ferruginea Stem Bark & $12.43 \pm 0.83^{a}$ & $10.95 \pm 0.71^{\mathrm{a}}$ & $20.71 \pm 1.04^{b}$ & $61.60 \pm 2.96^{c}$ \\
\hline C. papaya Leaf & $45.32 \pm 2.47^{a}$ & $35.20 \pm 1.07^{b}$ & $57.43 \pm 2.30^{\mathrm{c}^{* *}}$ & $61.60 \pm 2.96^{c}$ \\
\hline C. pentandra Stem Bark & $24.93 \pm 1.93^{\mathrm{a}}$ & $38.28 \pm 3.33^{b}$ & $10.85 \pm 0.67^{c}$ & $61.60 \pm 2.96^{d}$ \\
\hline C. paradisi Leaf & $20.35 \pm 1.01^{a}$ & $13.53 \pm 0.90^{b}$ & $32.72 \pm 2.15^{c}$ & $61.60 \pm 2.96^{d}$ \\
\hline C. ferruginea Leaf & $13.87 \pm 0.53^{a}$ & $12.63 \pm 0.49^{a}$ & $22.15 \pm 1.32^{b}$ & $61.60 \pm 2.96^{c}$ \\
\hline F. asperifolia Leaf & $26.51 \pm 2.09^{a}$ & $33.82 \pm 2.10^{\mathrm{a}}$ & $52.88 \pm 3.17^{b^{* *}}$ & $61.60 \pm 2.96^{b}$ \\
\hline F. exasperata Leaf & $9.25 \pm 0.52^{\mathrm{a}}$ & $18.38 \pm 0.38^{b}$ & $11.53 \pm 0.83^{a}$ & $61.60 \pm 2.96^{c}$ \\
\hline G. Iatifolium Leaf & $21.17 \pm 0.66^{a}$ & $13.87 \pm 0.14^{b}$ & $13.97 \pm 0.80^{b}$ & $61.60 \pm 2.96^{c}$ \\
\hline H. sabdariffa Stem Bark & $30.91 \pm 1.92^{a}$ & $20.51 \pm 1.12^{b}$ & $54.79 \pm 2.01^{\mathrm{c}^{* *}}$ & $61.60 \pm 2.96^{c}$ \\
\hline H. umbellata Seed & $12.63 \pm 0.70^{\mathrm{a}}$ & $22.17 \pm 1.08^{\mathrm{b}}$ & $12.08 \pm 0.83^{a}$ & $61.60 \pm 2.96^{c}$ \\
\hline I. pulchra Leaf & $11.68 \pm 0.90^{a}$ & $22.88 \pm 2.12^{b}$ & $12.27 \pm 0.97^{a}$ & $61.60 \pm 2.96^{c}$ \\
\hline K. senegalensis Leaf & $20.93 \pm 0.74^{a}$ & $19.68 \pm 0.62^{\mathrm{a}}$ & $10.08 \pm 0.42^{b}$ & $61.60 \pm 2.96^{c}$ \\
\hline K. senegalensis Stem Bark & $37.66 \pm 1.01^{\mathrm{a}}$ & $20.12 \pm 1.12^{\mathrm{b}}$ & $63.20 \pm 2.90^{\mathrm{c}^{* *}}$ & $61.60 \pm 2.96^{c}$ \\
\hline M. indica Leaf & $39.42 \pm 1.19^{a}$ & $42.83 \pm 0.50^{a}$ & $39.00 \pm 1.37^{a}$ & $61.60 \pm 2.96^{b}$ \\
\hline M. indica Stem Bark & $35.14 \pm 1.36^{a}$ & $17.37 \pm 0.47^{b}$ & $32.12 \pm 1.72^{a}$ & $61.60 \pm 2.96^{c}$ \\
\hline M. Lucida Leaf & $11.57 \pm 0.43^{a}$ & $19.97 \pm 0.36^{b}$ & $10.88 \pm 0.57^{a}$ & $61.60 \pm 2.96^{c}$ \\
\hline N. latifolia Leaf & $31.17 \pm 1.09^{a}$ & $40.95 \pm 1.15^{\mathrm{b}}$ & $42.43 \pm 1.33^{b}$ & $61.60 \pm 2.96^{c}$ \\
\hline O. gratissimum Leaf & $57.99 \pm 2.30^{\mathrm{a}^{* *}}$ & $20.40 \pm 1.10^{b}$ & $63.96 \pm 1.69^{a^{* *}}$ & $61.60 \pm 2.96^{a}$ \\
\hline P. biglobosa Stem Bark & $65.42 \pm 3.48^{\mathrm{a}^{* *}}$ & $22.46 \pm 1.06^{b}$ & $46.22 \pm 4.07^{c}$ & $61.60 \pm 2.96^{a}$ \\
\hline V. album Leaf & $21.02 \pm 1.08^{a}$ & $13.27 \pm 1.07^{b}$ & $8.78 \pm 0.62^{c}$ & $61.60 \pm 2.96^{d}$ \\
\hline V. album Seed & $18.37 \pm 0.26^{a}$ & $17.40 \pm 0.17^{a}$ & $10.38 \pm 0.10^{b}$ & $61.60 \pm 2.96^{c}$ \\
\hline
\end{tabular}

Data are presented as mean \pm SD of three replicates at $240 \mu \mathrm{g} / \mathrm{ml}$. Values with different letters along the same row for each plant part are significantly different, $* * p<0.05$ compared favourably with ascorbic acid.

of its potential antioxidant activity. ${ }^{30}$ The ferric reducing assay is widely used to evaluate the antioxidant potential of polyphenols. ${ }^{31}$ Again, extracts from the seven plants earlier identified demonstrate good ferric reducing ability which indicates their strong antioxidant activity. This property enables herbs to mop up noxious toxic metabolites released during pathological states and confer protection on the affected organs. The possible mechanism by which the extract exerts its effect may be by prevention of chain initiation or decomposition of peroxides. ${ }^{32}$ The reductive capability of the extract was concentration dependent which is an indication that antioxidant activity is likely to increase with higher concentrations. Many of the complications of diabetes have been linked to oxidative stress; and antioxidants have been considered as treatments. ${ }^{33,34}$ Hence, it could be suggested that antioxidant action may be an important property of plant medicines associated with diabetes. The present study has clearly demonstrated the antioxidant capabilities of $A$. occidentale, C. papaya, F. asperifolia, $H$. sabdariffa, $K$. senegalensis, $O$. gratissimum and P. biglobosa; and their activity is comparable to ascorbic acid, a standard antioxidant.

$\alpha$-amylase is one of the main enzymes in human body that is responsible for the breakdown of starch to more simple sugars. The enzyme hydrolyzes complex polysaccharides to produce oligosaccharides and disaccharides which are then broken down into monosaccharides by $\alpha$-glycosidase. The monosaccharides are then absorbed through the small intestine into the hepatic portal vein and increase postprandial glucose levels. ${ }^{35,36}$ It has been established that $\alpha$-amylase inhibitors from natural 
Table 6: Percentage $\alpha$-Amylase Inhibition by Solvent Extracts of Different Plant Parts Relative to Acarbose.

\begin{tabular}{|c|c|c|c|c|}
\hline \multicolumn{4}{|c|}{ Extracts } & \multirow[b]{2}{*}{ Acarbose } \\
\hline Plant/Part & Ethanol & Methanol & Distilled Water & \\
\hline A. cordifolea Leaf & $28.17 \pm 1.36^{\mathrm{a}}$ & $16.01 \pm 1.67^{b}$ & $13.96 \pm 1.06^{b}$ & $45.20 \pm 4.06^{c}$ \\
\hline A. occidentale Leaf & $48.35 \pm 3.02^{\mathrm{a}^{* *}}$ & $22.10 \pm 1.08^{b}$ & $40.80 \pm 2.97^{a^{* *}}$ & $45.20 \pm 4.06^{a}$ \\
\hline A. djalonensis Leaf & $19.58 \pm 2.73^{a}$ & $20.42 \pm 2.53^{a}$ & $21.67 \pm 2.91^{\mathrm{a}}$ & $45.20 \pm 4.06^{b}$ \\
\hline B. ferruginea Leaf & $20.91 \pm 1.16^{a}$ & $24.89 \pm 1.81^{a}$ & $20.21 \pm 1.32^{a}$ & $45.20 \pm 4.06^{b}$ \\
\hline B. ferruginea Seed & $14.92 \pm 1.15^{\mathrm{a}}$ & $18.83 \pm 1.08^{a}$ & $29.07 \pm 1.04^{b}$ & $45.20 \pm 4.06^{c}$ \\
\hline B. ferruginea Stem Bark & $19.95 \pm 1.25^{a}$ & $17.13 \pm 1.21^{a}$ & $31.53 \pm 1.01^{b}$ & $45.20 \pm 4.06^{c}$ \\
\hline C. papaya Leaf & $21.23 \pm 1.07^{a}$ & $11.42 \pm 0.78^{b}$ & $40.76 \pm 3.20^{c^{* *}}$ & $45.20 \pm 4.06^{c}$ \\
\hline C. pentandra Stem Bark & $21.62 \pm 1.06^{\mathrm{a}}$ & $30.49 \pm 1.03^{b}$ & $11.89 \pm 0.75^{c}$ & $45.20 \pm 4.06^{\circ}$ \\
\hline C. paradisi Leaf & $19.60 \pm 1.04^{\mathrm{a}}$ & $10.44 \pm 0.72^{b}$ & $19.04 \pm 0.94^{\mathrm{a}}$ & $45.20 \pm 4.06^{\circ}$ \\
\hline C. ferruginea Leaf & $18.60 \pm 0.48^{a}$ & $16.88 \pm 1.05^{a}$ & $28.36 \pm 1.04^{b}$ & $45.20 \pm 4.06$ \\
\hline F. asperifolia Leaf & $15.16 \pm 0.79^{a}$ & $25.60 \pm 1.01^{b}$ & $44.50 \pm 2.18^{\mathrm{c}^{* *}}$ & $45.20 \pm 4.06^{c}$ \\
\hline F. exasperata Leaf & $12.51 \pm 0.55^{a}$ & $19.70 \pm 0.40^{b}$ & $20.95 \pm 0.34^{b}$ & $45.20 \pm 4.06^{c}$ \\
\hline G. latifolium Leaf & $23.47 \pm 1.67^{a}$ & $12.18 \pm 0.90^{b}$ & $13.76 \pm 0.76^{b}$ & $45.20 \pm 4.06^{c}$ \\
\hline H. sabdariffa Stem Bark & $28.25 \pm 0.91^{a}$ & $17.11 \pm 1.01^{b}$ & $46.79 \pm 1.80^{c^{* *}}$ & $45.20 \pm 4.06^{c}$ \\
\hline H. umbellata Seed & $22.50 \pm 0.58^{a}$ & $31.75 \pm 1.04^{b}$ & $28.91 \pm 2.01^{b}$ & $45.20 \pm 4.06^{c}$ \\
\hline I. pulchra Leaf & $23.18 \pm 0.53^{a}$ & $34.45 \pm 0.45^{b}$ & $25.10 \pm 0.41^{a}$ & $45.20 \pm 4.06^{c}$ \\
\hline K. senegalensis Leaf & $21.61 \pm 1.04^{a}$ & $12.48 \pm 0.49^{b}$ & $18.56 \pm 0.69^{a}$ & $45.20 \pm 4.06$ \\
\hline K. senegalensis Stem Bark & $39.66 \pm 2.01^{\mathrm{a}^{* *}}$ & $15.12 \pm 1.76^{b}$ & $44.40 \pm 3.80^{\mathrm{a}^{* *}}$ & $45.20 \pm 4.06^{\circ}$ \\
\hline M. indica Leaf & $12.96 \pm 1.06^{a}$ & $22.73 \pm 2.01^{b}$ & $18.81 \pm 1.07^{b}$ & $45.20 \pm 4.06^{c}$ \\
\hline M. indica Stem Bark & $29.14 \pm 1.06^{a}$ & $13.43 \pm 1.01^{b}$ & $25.62 \pm 1.88^{a}$ & $45.20 \pm 4.06^{c}$ \\
\hline M. Lucida Leaf & $20.81 \pm 1.62^{\mathrm{a}}$ & $23.55 \pm 1.75^{\mathrm{a}}$ & $11.50 \pm 0.72^{b}$ & $45.20 \pm 4.06^{c}$ \\
\hline N. latifolia Leaf & $14.99 \pm 1.04^{\mathrm{a}}$ & $24.82 \pm 1.22^{\mathrm{b}}$ & $27.98 \pm 2.16^{b}$ & $45.20 \pm 4.06^{c}$ \\
\hline O. gratissimum Leaf & $48.99 \pm 3.30^{\mathrm{a}^{* *}}$ & $26.90 \pm 2.52^{b}$ & $44.90 \pm 3.60^{\mathrm{a}^{* *}}$ & $45.20 \pm 4.06^{c}$ \\
\hline P. biglobosa Stem Bark & $46.45 \pm 2.14^{\mathrm{a}^{* *}}$ & $20.22 \pm 1.81^{b}$ & $49.62 \pm 3.17^{\mathrm{a}^{* *}}$ & $45.20 \pm 4.06^{a}$ \\
\hline V. album Leaf & $11.89 \pm 1.36^{\mathrm{a}}$ & $22.95 \pm 0.62^{\mathrm{b}}$ & $11.32 \pm 0.68^{a}$ & $45.20 \pm 4.06^{c}$ \\
\hline V. album Seed & $29.07 \pm 2.03^{a}$ & $25.25 \pm 2.45^{\mathrm{a}}$ & $11.31 \pm 0.82^{b}$ & $45.20 \pm 4.06$ \\
\hline
\end{tabular}

Data are presented as mean \pm SD of three determinations at $240 \mu \mathrm{g} / \mathrm{ml}$. Values with different letters along the same row for each plant part are significantly different, ** $p<0.05$ compared favourably with acarbose.

sources play a significant role in diabetes management and control. This is achieved via a decrease in postprandial hyperglycemia through inhibition of $\alpha$-amylase actions. ${ }^{37}$ From our findings, extracts of $A$. occidentale, C. papaya, F. asperifolia, H. sabdariffa, K. senegalensis, $O$. gratissimum and P. biglobosa demonstrated significant $\alpha$-amylase inhibition, indicating their potential role as an antidiabetic agent. This finding is in agreement with previous studies using other medicinal plants. ${ }^{22,37}$ Hence, this study support the case that natural products from medicinal plants have $\alpha$-amylase inhibitory activity and could be utilized as a successful therapy for the management of postprandial hyperglycemia with minimal adverse effects.

To further explore the antidiabetic potential of the plant extracts, their ability to inhibit glycosylation of hemoglobin was evaluated. Glycosylation refers to the non-enzymatic reaction between reducing sugars and proteins (hemoglobin, albumin) and usually contributes enormously to the formation of advanced glycation end products. ${ }^{38}$ Human beings minimize the production of reactive oxygen species by enzymatic and non-enzymatic antioxidant mechanism, which plays a key role in many degenerative diseases including diabetes. High glucose levels in body leads to its binding to hemoglobin which may result in the production of reactive oxygen species. Previous studies have reported that end products of glycosylation can be inhibited by plant extracts. ${ }^{39}$ It is evident from our study that the same set of plants as obtained for $\alpha$-amylase demonstrated significant inhibition of haemoglobin glycosylation which was comparable to gallic acid. This further indicates the potential role of these plants as an antidiabetic agent. 


\section{Table 7: Percentage Inhibition of Haemoglobin Glycosylation by Solvent Extracts of Different Plant Parts Rela-} tive to Gallic Acid.

\begin{tabular}{|c|c|c|c|c|}
\hline \multicolumn{4}{|c|}{ Extracts } & \multirow[b]{2}{*}{ Gallic Acid } \\
\hline Plant/Part & Ethanol & Methanol & Distilled Water & \\
\hline A. cordifolea Leaf & $37.45 \pm 2.57^{a}$ & $22.80 \pm 1.50^{b}$ & $20.48 \pm 1.08^{b}$ & $63.48 \pm 3.75^{c}$ \\
\hline A. occidentale Leaf & $68.53 \pm 3.95^{\mathrm{a}^{* *}}$ & $34.50 \pm 1.29^{b}$ & $65.48 \pm 2.47^{\mathrm{a}^{* *}}$ & $63.48 \pm 3.75^{\mathrm{a}}$ \\
\hline A. djalonensis Leaf & $12.60 \pm 1^{\mathrm{a}}$ & $15.70 \pm 1.86^{\mathrm{a}}$ & $25.00 \pm 1.12^{b}$ & $63.48 \pm 3.75^{c}$ \\
\hline B. ferruginea Leaf & $24.55 \pm 1.44^{a}$ & $14.90 \pm 1.39^{b}$ & $33.37 \pm 2.73^{c}$ & $63.48 \pm 3.75^{d}$ \\
\hline B. ferruginea Seed & $6.14 \pm 0.52^{\mathrm{a}}$ & $8.74 \pm 0.72^{\mathrm{a}}$ & $14.39 \pm 1.03^{b}$ & $63.48 \pm 3.75^{c}$ \\
\hline B. ferruginea Stem Bark & $14.63 \pm 0.89^{a}$ & $13.32 \pm 0.80^{a}$ & $25.27 \pm 0.58^{\mathrm{b}}$ & $63.48 \pm 3.75^{c}$ \\
\hline C. papaya Leaf & $32.33 \pm 1.52^{\mathrm{a}}$ & $21.41 \pm 1.15^{b}$ & $68.47 \pm 3.63^{\mathrm{c}^{* *}}$ & $63.48 \pm 3.75^{c}$ \\
\hline C. pentandra Stem Bark & $28.34 \pm 0.79^{a}$ & $10.37 \pm 0.71^{b}$ & $20.05 \pm 0.66^{c}$ & $63.48 \pm 3.75^{\mathrm{d}}$ \\
\hline C. paradisi Leaf & $23.67 \pm 1.80^{a}$ & $20.30 \pm 2.95^{\mathrm{a}}$ & $36.21 \pm 2.17^{b}$ & $63.48 \pm 3.75^{c}$ \\
\hline C. ferruginea Leaf & $9.27 \pm 0.65^{\mathrm{a}}$ & $7.11 \pm 0.96^{a}$ & $18.94 \pm 0.91^{b}$ & $63.48 \pm 3.75^{c}$ \\
\hline F. asperifolia Leaf & $24.16 \pm 2.61^{a}$ & $37.48 \pm 1.28^{b}$ & $68.44 \pm 2.58^{\mathrm{c}^{* *}}$ & $63.48 \pm 3.75^{c}$ \\
\hline F. exasperata Leaf & $7.88 \pm 0.33^{\mathrm{a}}$ & $8.04 \pm 0.49^{a}$ & $17.04 \pm 1.07^{b}$ & $63.48 \pm 3.75^{c}$ \\
\hline G. latifolium Leaf & $18.83 \pm 1.08^{a}$ & $6.87 \pm 0.33^{b}$ & $7.67 \pm 0.52^{b}$ & $63.48 \pm 3.75^{c}$ \\
\hline H. sabdariffa Stem Bark & $38.20 \pm 1.92^{a}$ & $22.61 \pm 2.26^{b}$ & $63.75 \pm 2.39^{c}$ & $63.48 \pm 3.75^{c}$ \\
\hline H. umbellata Seed & $16.90 \pm 1.35^{a}$ & $8.65 \pm 0.69^{b}$ & $16.50 \pm 1.82^{\mathrm{a}}$ & $63.48 \pm 3.75^{c}$ \\
\hline I. pulchra Leaf & $26.72 \pm 1.30^{\mathrm{a}}$ & $15.97 \pm 1.04^{b}$ & $13.48 \pm 0.82^{b}$ & $63.48 \pm 3.75^{c}$ \\
\hline K. senegalensis Leaf & $28.95 \pm 1.62^{\mathrm{a}}$ & $26.05 \pm 1.36^{a}$ & $14.17 \pm 0.85^{b}$ & $63.48 \pm 3.75^{c}$ \\
\hline K. senegalensis Stem Bark & $59.66 \pm 2.01^{\mathrm{a}^{* *}}$ & $23.08 \pm 1.71^{b}$ & $61.00 \pm 2.80^{\mathrm{a}^{* *}}$ & $63.48 \pm 3.75^{a}$ \\
\hline M. indica Leaf & $23.90 \pm 1.52^{\mathrm{a}}$ & $37.54 \pm 1.13^{b}$ & $21.04 \pm 1.16^{a}$ & $63.48 \pm 3.75^{c}$ \\
\hline M. indica Stem Bark & $36.14 \pm 2.36^{a}$ & $23.77 \pm 1.74^{b}$ & $40.12 \pm 3.88^{a}$ & $63.48 \pm 3.75^{c}$ \\
\hline M. Lucida Leaf & $8.66 \pm 0.49^{a}$ & $10.95 \pm 0.86^{a}$ & $19.46 \pm 0.46^{b}$ & $63.48 \pm 3.75^{c}$ \\
\hline N. Iatifolia Leaf & $13.55 \pm 1.09^{a}$ & $20.78 \pm 0.92^{b}$ & $36.59 \pm 1.68^{c}$ & $63.48 \pm 3.75^{d}$ \\
\hline O. gratissimum Leaf & $62.14 \pm 2.36^{\mathrm{a}^{* *}}$ & $40.74 \pm 1.45^{b}$ & $58.12 \pm 2.88^{\mathrm{a}^{* *}}$ & $63.48 \pm 3.75^{a}$ \\
\hline P. biglobosa Stem Bark & $65.42 \pm 2.84^{\mathrm{a}^{* *}}$ & $36.46 \pm 1.50^{b}$ & $59.24 \pm 2.17^{\mathrm{a}^{* *}}$ & $63.48 \pm 3.75^{a}$ \\
\hline V. album Leaf & $19.54 \pm 1.09^{a}$ & $18.92 \pm 0.73^{a}$ & $10.12 \pm 0.35^{b}$ & $63.48 \pm 3.75^{c}$ \\
\hline V. album Seed & $11.45 \pm 0.63^{\mathrm{a}}$ & $9.25 \pm 0.48^{a}$ & $5.51 \pm 0.35^{b}$ & $63.48 \pm 3.75^{c}$ \\
\hline
\end{tabular}

Data are presented as mean \pm SD of three determinations at $240 \mu \mathrm{g} / \mathrm{ml}$. Values with different letters along the same row for each plant part are significantly different, $* *$ $p<0.05$ compared favourably with gallic acid.

\section{CONCLUSION}

Our findings revealed a positive correlation between the polyphenol/flavonoid concentration and in vitro antidiabetic/antioxidant activities of plant extracts. Hence, these in vitro assays indicated that plants extracts may be a significant source of natural antioxidant and antidiabetic agents. However, out of the 21 medicinal plants examined in this study, which are used in Nigerian traditional medicine for the treatment of diabetes, only seven actually demonstrated antidiabetic activity based on the scientific indices employed. This does not suggest that the others cannot find medicinal usefulness but further implies that more scientific investigations should be carried out in order to validate the antidiabetic activity of medicinal plants as claimed by traditional healers. Finally, our findings have justified and offered scientific credence to the folkloric use of some of the herbs in Nigerian as antidiabetic agents.

\section{ACKNOWLEDGEMENT}

This research was supported by funds from the publication subsidy of Prof. F.B. Lewu, Cape Peninsula University of Technology, Wellington, South Africa.

\section{CONFLICT OF INTEREST}

The authors declare no conflict of interest.

\section{ABBREVIATIONS}

IDDM: Insulin-dependent diabetes mellitus; NIDDM: Non-insulin-dependent diabetes mellitus; DNS: Dinitrosalicyclic acid; DMSO: Dimethyl sulfoxide. 


\section{REFERENCES}

1. Khan A, Zaman G, Anderson, RA. Bay leaves improve glucose and lipid profile of people with Type 2 diabetes. J Clin Biochem Nutr. 2009;44(1):52-6.

2. Moller DE, Flier JS. Insulin resistance-mechanism, syndromes and implications. N Engl J Med. 1991;325(13):938-48.

3. Fasanmade OA, Dagogo-Jack S. Diabetes care in Nigeria. Annals Global Health. 2015;81(6):821-9.

4. Health24. Prevalence of diabetes in South Africa. https://www.health24. com/Medical/Diabetes/About-diabetes/Diabetes-tsunami-hits-SouthAfrica-20130210; 2017.

5. Notkins AL. Immunologic and genetic factors in type 1 diabetes. J Biol Chem. 2002;277(46):43545-8

6. Harrison LC, Honeyman MC. Cow's milk and type 1 diabetes: the real debate is about mucosal immune function. Diabetes 1999;48(8):1501-7.

7. Zimmet P, Dowse G, Finch C, Serjeantson S, King H. The epidemiology and natural history of NIDDM - Lessons from the South Pacific. Diabetes Metab Rev. 1990;6(2):91-124.

8. Afolayan AJ, Sunmonu TO. Protective role of Artemisia afra aqueous extract on tissue antioxidant systems in streptozotocin-induced diabetic rats. Afr J Trad Compl Alt Med. 2013;10(1):15-20.

9. Oberley LW. Free radicals and diabetes. Free Rad Biol Med. 1988;5(2):113-24.

10. Mullarkey CJ, Edelstein D, Brownlee L. Free radical generation by early glycation products: A mechanism for accelerated atherogenesis in diabetes. Biochem Biophys Res Commun. 1990;173(3):932-9.

11. Strain JJ. Disturbances of micronutrient and antioxidant status in diabetes. Proc Nutr Soc. 1991;50(3):591-604.

12. Baynes JW. Role of oxidative stress in development of complications in diabetes. Diabetes 1991;40(4):405-12.

13. Modak M, Dixit P, Londhe J, Ghaskadbi S, Devasagayam TPA. Indian herbs and herbal drugs used for the treatment of diabetes. J Clin Biochem Nutr. 2007;40(3):163-73.

14. Ali H, Houghton PJ Soumyanath A. a-amylase inhibitory activity of some Malaysian plants used to treat diabetes; with particular reference to Phyllanthus amarus. J Ethnopharmacol. 2006;107(3):449-55.

15. Sunmonu TO, Van SJ. Phytotoxicity evaluation of six fast-growing tree species in South Africa. South Afr J Bot. 2014;90:101-6

16. Wolfe K, Wu X, Liu RH. Antioxidant activity of apple peels. J Agric Food Chem. 2003;51(3):609-14.

17. Ordon Ez AAL, Gomez JD, Vattuone MA, Isla MI. Antioxidant activities of Sechium edule (Jacq.) Swart extracts. Food Chem. 2006;97(3):452-8.

18. Oyaizu M. Studies on potent of browning reactions: Antioxidative activities of products of browning reaction prepared from glucosamine. Japan J. Nutr. 1986;44:307-15

19. McCue $P$, Shetty $K$. Inhibitory effects of rosmarinic acid extracts on porcine pancreatic amylase in vitro. Asia Pac J Clin Nutr. 2004;13(1):101-6.

20. Pal DK, Dutta S. Evaluation of antioxidant activity of the roots of Cyperus rotundus L. Indian J Pharm Sci. 2006;68(2):256-8.

21. Yazdanparast $\mathrm{R}$, Ardestani $A$. In vitro antioxidant and free radical scavenging activity of Cyperus rotundus. J Med Food. 2007;10(4):667-74.

22. Mohammed A, Koorbanally NA, Islam MS. Phytochemistry, antioxidative activity and inhibition of key enzymes linked to type 2 diabetes by various parts of Aframomum melegueta in vitro. Acta Pol Pharm -Drug Res. 2016;73(2):403-17.
23. Sellappan S, Akoh CC, Krewer G. Phenolic compounds and antioxidant capacity of Georgia-grown blueberries and blackberries. J Agric Food Chem. 2002;50(8):2432-8.

24. Gorinstein S, Zachwieja Z, Katrich E, Pawelzik E, Haruenkit R, Trakhtenberg S, et al. Comparison of the contents of the main antioxidant compounds and the antioxidant activity of white grapefruit and his new hybrid. LWT-Food Sci Technol. 2004;37(3):337-43.

25. Hodzic Z, Pasalic H, Memisevic A, Scrabovic M, Saletovic M, Poljakovic M. The influence of total phenols content on antioxidant capacity in the whole grain extracts. Eur J Sci Res. 2009;28(3):471-7.

26. Zheng W, Wang SY. Antioxidant activity and phenolic compounds in selected herbs. J Agric Food Chem. 2001;49(11):5165-70.

27. Brand-Williams W, Culvelier ME, Berset C. Use of a free-radical method to evaluate antioxidant activity. Food Sci Technol-Leb. 1995;28(1):25-30.

28. Adefegha SA, Oboh G. Water extractable phytochemicals from some Nigerian spices inhibit $\mathrm{Fe}^{2+}$-induced lipid peroxidation in rat's brain - In vitro. J Food Process Technol. 2011;2:104. doi:10.4172/2157-7110.1000104.

29. Onoja SO, Omeh YN, Ezeja MI, Chukwu MN. Evaluation of the in vitro and in vivo antioxidant potentials of Aframomum melegueta methanolic seed extract. J Trop Med. 2014;1:159343. doi: 10.1155/2014/159343.

30. Meir S, Kanner J, Akiri B, Hadas SP. Determination and involvement of aqueous reducing compounds in oxidative defense systems of various senescing leaves. J Agric Food Chem. 1995;43(7):1813-9.

31. Luximon-Ramma A, Bahorun T, Soobrattee AM, Aruoma OI. Antioxidant activity of phenolic, proanthocyanidin flavonoid components in extracts of Acacia fistula. J Agric Food Chem. 2005;50(18):5042-7.

32. Yildidrim A, Mavi A, Oktay M, Kara AA, Algur OF, Bilaloglu V. Comparison of antioxidant and antimicrobial activities of Tilia (Tilia argentea Desf. Ex. DC), Sage (Savia triloba L.) and Black Tea (Camellia sinensis) extracts. J Agric Food Chem. 2000;48(10):5030-4.

33. Reaven PD, Herold DA, Barnett J, Edelman S. Effects of vitamin E on susceptibility of low-density lipoprotein and low-density lipoprotein subfractions to oxidation and on protein glycation in NIDDM. Diabetes Care. 1995;18(6):807-16.

34. Cunningham JJ. Micronutrients as nutriceutical intervention in diabetes mellitus. J Am Coll Nutr. 1995;17(1):7-10.

35. Ranilla LG, Kwon YI, Apostolidis E, Shetty K. Phenolic compounds, antioxidant activity and in vitro inhibitory potential against key enzymes relevant for hyperglycemia and hypertension of commonly used medicinal plants, herbs and spices in Latin America. Biores Technol. 2010;101(12):4676-89.

36. El-Kaissi S, Sherbeeni S. Pharmacological management of type 2 diabetes mellitus: An update. Curr Diabetes Rev. 2011;7(6):392-405.

37. Adefegha SA, Oboh $\mathrm{G}$. In vitro inhibition activity of polyphenol-rich extracts from Syzygium aromaticum (L.) Merr. and Perry (Clove) buds against carbohydrate hydrolyzing enzymes linked to type 2 diabetes and $\mathrm{Fe}^{2+}$ induced lipid peroxidation in rat pancreas. Asian Pac J Trop Biomed. 2012;2(10):774-81.

38. Yamagishi S, Ueda S, Matsui T, Nakamura K, Okuda S. Role of advanced glycation end products (AGEs) and oxidative stress in diabetic retinopathy. Curr Pharm Des. 2008;14(10):962-8.

39. Madhuri VR, Begum SP, Begum HS, Kumar PA, Mahesh S, Karimulla S, et al. Evaluation of in vitro anti-diabetic activity on ethanolic extract of aerial parts of Murraya koenigii. Indian J Res Pharm Biotechnol. 2016;4(3):147-53.

\section{PICTORIAL ABSTRACT}

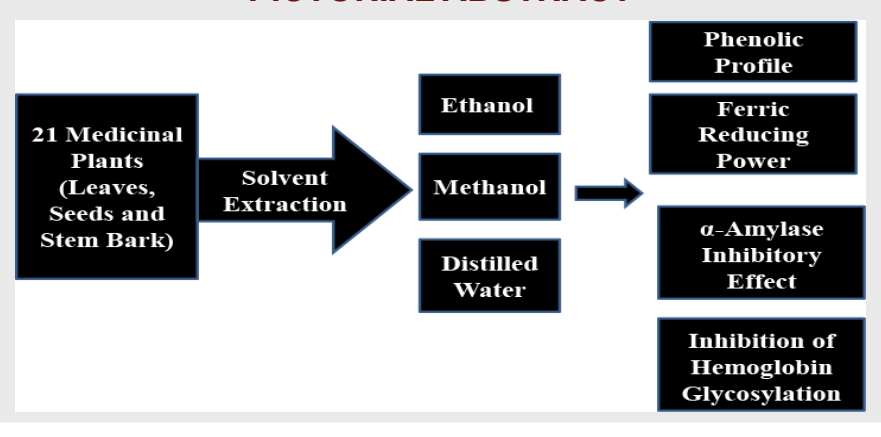

Indian Journal of Pharmaceutical Education and Research | Vol 53 | Issue 2 | Apr-Jun, 2019 


\section{ABOUT AUTHORS}

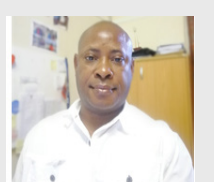

Professor Francis Lewu, obtained BSc (Agriculture) from the University of Agriculture Abeokuta and MSc Agronomy (Soil Microbiology) in the University of Ibadan, Nigeria. He started his career as a Genebank Research Assistant in the International Institute of Tropical Agriculture, IITA, Nigeria; and later proceeded to study $\mathrm{PhD}$ in Botany with specialization in plant genetic conservation and propagation at the University of Fort Hare, South Africa. Lewu concentrates his research effort on the autecology and propagation of medicinals and alternative cultivation protocols for field crops and horticultural species. His latest research interest is focused on the influence of nanomaterials on efficacy of medicinal species and their ameliorating effects on biochemicals of screened materials through different propagation and screening methods.

\section{SUMMARY}

- The present study investigated the in vitro antidiabetic activity of 21 commonly used medicinal plants used for the treatment of diabetes by traditional healers in Nigeria.

- Solvents extracts of 7 plants namely $A$. occidentale, C. papaya, F. asperifolia, H. sabdariffa, K. senegalensis, O. gratissimum and P. biglobosa had considerable concentrations of polyphenolic compounds and demonstrated significant antioxidant/antidiabetic activity.

- Generally, plant parts extracted with distilled water showed better antidiabetic activity compared to ethanol and methanol.

- Overall, findings from this study indicate that plants extracts may be a significant source of natural antioxidant and antidiabetic agents.

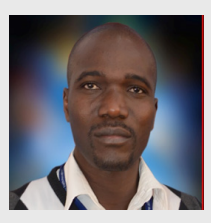

Professor Taofik Olatude Sunmonu graduated from the University of Ilorin, Ilorin, Nigeria in 1998 with a B.Sc. degree in Biochemistry. He obtained his M.Sc. and Ph.D. degrees (Biochemistry) from the same University in 2002 and 2006 respectively. He was awarded postdoctoral fellowship and training at Research Centre for Phytomedicine, University of Fort Hare, Alice, South Africa (2009), Alpha Care Centre, Worcestershire, Birmingham, United Kingdom (2011) and Research Centre for Plant Growth and Development, University of KwaZulu-Natal, Pietermaritzburg, South Africa (2013). He was also offered the position of a Visiting Researcher at Cape Peninsula University of Technology, Wellington, South Africa (2018). He has to his credit over 50 in-depth scientific articles, which are published in reputable journals in the areas of Environmental Toxicology, Phytomedicine and Plant Biochemistry.

Cite this article: Sunmonu TO, Lewu FB. Phytochemical Analysis, in vitro Antioxidant Activity and Inhibition of Key Diabetic Enzymes by Selected Nigerian Medicinal Plants with Antidiabetic Potential. Indian J of Pharmaceutical Education and Research. 2019;53(2):250-60. 